\title{
TAX POLICY AND ENTREPRENEURSHIP IN THE PRESENCE OF ASYMMETRIC INFORMATION IN CAPITAL MARKETS
}

\author{
Clemens Fuest \\ BERND HUBER \\ PHILIPP TILLESSEN
}

CESIFO WORKING PAPER No. 872

CATEGORY 1: PUBLIC FINANCE

FEBRUARY 2003

\author{
PRESENTEd AT CESifo CONFERENCE ON VeNTURe CAPITAL AND \\ ENTREPRENEURSHIP, NOVEMBER 2002 \\ An electronic version of the paper may be downloaded \\ - from the SSRN website: www.SSRN.com \\ - from the CESifo website: www.CESifo.de
}




\title{
TAX POLICY AND ENTREPRENEURSHIP IN THE PRESENCE OF ASYMMETRIC INFORMATION IN CAPITAL MARKETS
}

\begin{abstract}
This paper considers the implications of asymmetric information in capital markets for entrepreneurial entry and tax policy. In many countries, governments subsidize the creation of new firms. One possible justification for these subsidies is that capital markets for the financing of new firms do not function properly. We analyse this issue by assuming that entrepreneurs need outside financing for their projects and know more about the quality of their projects than outside investors. Entrepreneurs have the choice between carrying out their entrepreneurial projects or working as an employee. It turns out that asymmetric information in capital markets leads to too much rather than too little entrepreneurial entry. Therefore, the ptimal tax policy should discourage rather than subsidize entrepreneurial entry. We also nalyse the welfare effects of project screening and show that there is too much screening. Our policy conclusion is that subsidies for the foundation of firms must be based on reasons other than informational asymmetries in capital markets.
\end{abstract}

JEL Code: H21, G14, G32.

\author{
Clemens Fuest \\ University of Cologne \\ Department of Economics \\ Albertus Magnus Platz \\ 50923 Köln \\ Germany \\ clemens.fuest@uni-koeln.de
}

\author{
Bernd Huber \\ University of Munich \\ Department of Economics \\ Ludwigstr. 28 \\ 80539 München \\ Germany \\ huber.office@lrz.uni-muenchen.de
}

\author{
Philipp Tillessen \\ University of Cologne \\ Department of Economics \\ Albertus Magnus Platz \\ $50923 \mathrm{Köln}$ \\ Germany \\ p.tillessen@uni-koeln.de
}

The authors would like to thank Martin Dietz, Soren Bo Nielsen and participants of the CESifo Conference on "Venture Capital and Entrepreneurship" for very helpful comments and suggestions. The usual disclaimer applies. 


\section{Introduction}

Start-up firms are commonly thought to play an important role in fostering economic growth, innovation and employment. Therefore, governments in many countries frequently take measures at local and state levels to stimulate entrepreneurial activity. ${ }^{1}$ Although existing empirical studies suggest that public assistance programs improve the survival chances and enhance the employment growth rates of young firms ${ }^{2}$, no efficiency argument about such public policy can be derived from this correlation. An efficiency-based argument for public policies supporting start-up firms requires that market signals are somehow distorted, i.e. that market failure in the form of too little entrepreneurial entry exists. One argument to justify this policy are the alleged positive externalities of entrepreneurial activity. ${ }^{3}$ If start-up firms are the source of positive externalities, public policy intervention would be desirable. ${ }^{4}$ But it is an unresolved empirical issue whether the market produces too few or too many firms. ${ }^{5}$

Another important problem faced by entrepreneurs is the existence of capital market imperfections. Since start-ups require investments that usually far exceed the entrepreneur's own wealth, it is often necessary for new firms to raise outside finance. Here, entrepreneurs face two key problems. Firstly, outside investors know much less about the prospects of a young firm than the entrepreneurs themselves. This informational asymmetry is particularly severe in the case of young and innovative start-ups. Entrepreneurs setting up a new firm usually do not have their own track record, their market potential is unproven and they often lack collateral as well as managerial and commercial experience. Therefore the investors' money is exposed to formidable risk. The second problem is that the relationship between the entrepreneur and the financier suffers from moral hazard problems. For these reasons it is often argued that bank loans or equity finance by independent investors are difficult to obtain and that venture capital is better adapted to solve the special problems of financing early-stage business. $^{6}$

Much of the academic literature on public policy and capital market imperfections focuses on moral hazard problems in the agency relationship between venture capitalists and

\footnotetext{
${ }^{1}$ In Germany, for example, there are more than 500 different programs to encourage entrepreneurial entry. For an analysis of the different programs see Gebhardt and Schmidt (2001) or Keuschnigg and Nielsen (2001).

${ }^{2}$ For such an empirical investigation see Almus and Prantl (2001).

${ }^{3}$ For an overview and a systematization of positive externalities see Romer (1996).

${ }^{4}$ Gebhardt and Schmidt (2001), for example, argue that positive externalities justify subsidies for start-up firms.

${ }^{5}$ For further discussion on this point see Holtz-Eakin (2000).

${ }^{6}$ See Keuschnigg and Nielsen $(2000,2001,2002)$.
} 
entrepreneurs. Keuschnigg and Nielsen (2000, 2002) emphasize on the productive contribution of venture capitalists to the survival and success of start-up firms. They find that the effort of the venture capitalists tends to be inefficiently low in market equilibrium. As a consequence, they argue that there is room for welfare-enhancing tax policy interventions such as cutting the capital gains tax rates on small firms or subsidizing the revenues of the venture capitalists. Gompers and Lerner (1999) show empirically that changes in the capital gains tax rate significantly affect venture capital investment.

De Meza and Webb (1987) focus on adverse selection problems and show that asymmetric information in capital markets may lead to overinvestment. The tax policy implications of this tendency towards overinvestment are explored in De Meza and Webb (1988). Fuest et al (2000) also consider a model where the capital market suffers from adverse selection problems. They show that, if there is asymmetric information between entrepreneurs and outside investors, the capital structure of new firms will be distorted in favour of debt financing. In this situation, it is optimal to support equity financing through the tax system.

One important limitation of most of these contributions is that they do not consider the question of entrepreneurial entry itself, i.e. the number of entrepreneurs is taken as given. Exceptions are Gordon (1998) and DeMeza and Webb (2000). Gordon (1998) points out that the fiscal treatment of start-ups should depend on the motives behind firm formation. Gordon emphasises, for instance, the difference between innovative firms and copy-cat firms who follow the innovators. He recommends tax distortions favoring innovative firms. De Meza and Webb (2000) analyse a model with adverse selection and moral hazard and conclude that the government should discourage rather than encourage entrepreneurial entry, even in situations where credit rationing occurs.

This paper departs from the empirical observation that rates of failure are very high among newly founded firms, which suggests that there may be a problem of too many low quality projects being carried out. We analyse this argument in a simple partial equilibrium model of occupational choice, where potential entrepreneurs can choose between carrying out an entrepreneurial project and the alternative of working as employees. If they become entrepreneurs, they must finance their projects in a capital market which is plagued by informational asymmetries. We analyse the optimality of entrepreneurial entry and financing decisions under different assumptions about the set of financing instruments and the type of 
informational asymmteries. Our main result is that the existence of capital market imperfections does not constitute a reason for subsidizing entrepreneurial entry. In most of the cases we consider, the optimal tax policy should discourage rather than encourage entrepreneurial entry. ${ }^{7}$ We also analyze the role of project screening. Although project screening reduces the number of low quality projects, which c.p. improves efficiency, too many firms choose the screening option in the laisser faire equilibrium.

The structure of the paper is as follows. Section 2 gives a few examples of governmental measures in different countries to encourage entrepreneurial activity. In section 3 we compile a few statistics on entrepreneurial activity and survival rates of start ups in different countries. Section 4 includes our main reasoning showing that there is too much entrepreneurial entry due to capital market imperfections. In this section we first analyse entrepreneurial entry when debt financing without screening is the only source of finance, then we extend the analysis by introducing the possibility of screening. Subsequently we investigate the impact of equity financing. Section 5 considers the implications of the Stiglitz-Weiss ${ }^{8}$ argument for the optimality of entrepreneurial entry. Section 6 analyzes the role of screening in our model. Section 7 concludes.

\section{Public Policy Measures To Encourage Entrepreneurial Activity}

Given the strong link between entrepreneurship and economic growth, promoting entrepreneurship is at the top of the social, political and economic agenda in many countries around the world. Therefore, policy makers have increasingly developed and implemented strategies that nurture entrepreneurial activity. To illustrate this, a few examples of such public policy activities and their financial dimensions are presented below.

The "Multiannual Program for enterprise and entrepreneurship and in particular for small and medium sized enterprises (2001-2005)" was started by the European Community in December 2000. ${ }^{9} 450$ million Euros were spent just on the implementation of the program. The main objectives of this program are, among others, to promote entrepreneurship, to

\footnotetext{
${ }^{7}$ Our results are thus broadly in line with DeMeza and Webb (2000). The difference is that we derive these results from a much simpler model and that screening plays an important role in our analysis.

${ }^{8}$ Stiglitz and Weiss (1981) show how capital market imperfections due to informational asymmetries may lead to credit rationing.

${ }^{9}$ See European Council (2000).
} 
simplify and improve the regulatory framework and to improve the financial environment for entrepreneurs. To reach these objectives the program will aim at assisting the creation of businesses and at promoting specific policies which favour start ups. The financial instruments foreseen under the program are supposed to intervene in areas where there is major weakness in the financing of start ups, such as mutual guarantee schemes and other forms of venture and seed capital. The financing of start ups will further be supported by direct investment in specialised venture capital funds. The calculated expanses for the financial instruments are 317 million Euros over the period 2001-2005. ${ }^{10}$

In Germany, there are more than 500 different programs at federal, provincial and regional levels to encourage entrepreneurial entry. ${ }^{11}$ There are even programs supporting the study of entrepreneurship at universities. For instance, the German Federal Government, in cooperation with the "Deutsche Ausgleichsbank", set up 42 chairs for start-up studies in order to familiarize students with issues of entrepreneurship. ${ }^{12}$ The German Government also directly supports start ups with a set of financing assisting programs. In 2001 5,6 billion euros were made available for loans in the European Recovery Program at favourable interest rates. In addition, start ups were being assisted by programs of the two assistance banks: the "Deutsche Ausgleichsbank" and the "Kreditanstalt für Wiederaufbau". These banks gave more than 10 billion euros in 2001 to fund loans granted to start ups and small enterprises. Furthermore the so called "start up funding program" gives borrowers' banks an $80 \%$ release from liability and loan guarantees to provide the security required by banks. In the field of risk capital, funds provided by the two assistance banks mobilized more than a half billion euros in 2000 for young companies.

In the U.S., the Small Business Administration (SBA) is the largest single financial backer of small business and start ups among many other government agencies providing services and support to small and newly founded firms. It provides financial, technical and management assistance to help entrepreneurs start, run and grow their business. From 1991 to 2000 the SBA backed more than 94,6 billion U.S. dollars in loans to small business financing. Since 1958 the SBA's venture capital program provided more than 30 billion U.S. dollars for the financing of small and start up businesses. ${ }^{13}$

\footnotetext{
${ }^{10}$ See European Commission (2002).

${ }^{11}$ See Gebhardt and Schmidt (2001).

${ }^{12}$ See for this and the following measures of the German Government Bundesministerium für Wirtschaft und Technologie (2000).

${ }^{13}$ See SBA (2001).
} 


\section{Empirical Evidence On Entry and Survival Rates of New Firms}

In the preceding section it has been shown that in many countries numerous programs to encourage entrepreneurial activity exist. But the contribution of new firms to economic growth and employment is not only determined by their rate of birth, but also by the rate at which they exit. In this section, results from several statistical investigations about entrepreneurial entry and survival probabilities of start ups are presented.

The Global Entrepreneurship Monitor (GEM), a joint research initiative created in 1997 by Babson College and the London Business School, gives a good overview of entrepreneurial activities in many different countries around the world. In 2001 a representative sample of at least 2000 adults (persons between 20 and 64 years of age) in 29 countries was interviewed in order to systematically assess the level of start up activity or the prevalence of nascent firms (the proportion of adult population that is currently engaged in the process of creating a nascent business) and the prevalence of new young firms (the proportion of adult population that is involved in operating a business that is less than 3,5 years old), i.e., those that have survived the very early start-up phase. ${ }^{14}$

Table 1: Nascent Firm Prevalence Rate By Country ${ }^{15}$

\begin{tabular}{|c|c|c|c|}
\hline GEM Countries & $\begin{array}{c}\text { Percentage of } \\
\text { Adults }\end{array}$ & GEM Countries & $\begin{array}{l}\text { Percentage of } \\
\text { Adults }\end{array}$ \\
\hline Israel & 1,19 & Canada & 7,04 \\
\hline Netherlands & 2,59 & Sauth Africa & 7,24 \\
\hline Belgium & 3,36 & Ireland & 7,27 \\
\hline Russia & 3,65 & Poland & 7,41 \\
\hline Portugal & 3,93 & Korea & 7,66 \\
\hline Singapore & 4,10 & India & 7,77 \\
\hline Sweden & 4,19 & Hungary & 7,78 \\
\hline Japan & 4,26 & Italy & 7,82 \\
\hline United Kingdom & 4,94 & Argentina & 7,97 \\
\hline Denmark & 5,31 & U.S.A. & 8,19 \\
\hline Germany & 5,39 & Australia & 8,97 \\
\hline Spain & 5,62 & Brazil & 9,24 \\
\hline Norway & 5,73 & New Zealand & 9,32 \\
\hline Finland & 5,98 & Mexico & 12,69 \\
\hline France & 6,35 & All countries & 6,27 \\
\hline
\end{tabular}

${ }_{15}^{14}$ See Reynolds, et al (2001).

15 Source: GEM 2001. 
Table 2: New Firm Prevalence Rates By Country ${ }^{16}$

\begin{tabular}{|c|c|c|c|}
\hline GEM Countries & $\begin{array}{l}\text { Percentage of } \\
\text { Adults }\end{array}$ & GEM Countries & $\begin{array}{c}\text { Percentage of } \\
\text { Adults }\end{array}$ \\
\hline Japan & 0,82 & Russia & 3,26 \\
\hline France & 0,88 & Finland & 3,34 \\
\hline Belgium & 1,23 & U.S.A. & 3,46 \\
\hline South Africa & 2,14 & India & 3,48 \\
\hline Spain & 2,16 & Hungary & 3,64 \\
\hline Singapore & 2,20 & Netherlands & 3,80 \\
\hline Germany & 2,32 & Canada & 3,94 \\
\hline Italy & 2,35 & Israel & 4,79 \\
\hline Sweden & 2,48 & Ireland & 4,85 \\
\hline Argentina & 2,54 & Brazil & 4,98 \\
\hline Poland & 2,58 & Mexico & 6,05 \\
\hline United Kingdom & 2,74 & New Zealand & 6,31 \\
\hline Denmark & 2,76 & Korea & 7,19 \\
\hline Norway & 2,97 & Australia & 7,24 \\
\hline Portugal & 3,16 & All Countries & 3,42 \\
\hline
\end{tabular}

Table 1 and 2 show the results from the GEM 2001. The most striking point in the context of this paper is that in most countries the Prevalence Rate of New Firms is much lower than the Prevalence Rate of Nascent Firms. The average New Firm Prevalence Rate for all countries $(3,42 \%)$ is just a little bit more than half of the average Nascent Firm Prevalence Rate $(6,27 \%)$ for all countries. This ratio may provide a very rough measure of the sustainability of start ups. Thus, it may be assumed that a very high number of entrepreneurs do not survive the early start up phase.

These figures are only valid within the GEM project and using the GEM data. Since the taken sample is only 2000 adults in some countries and since the method of the survey changed a slightly over the years, the data should not be seen as accurate portrayals of survival rates. Therefore, other calculations of survival rates for some countries are represented below.

Table 3 is based on OECD information and it shows the probabilities of cohorts of firms that entered the market from the late 1980s to the 1990s to survive the first two, four and seven years for different countries from western Europe and North America.

\footnotetext{
${ }^{16}$ Source: GEM 2001.
} 
Table 3: Survival Probabilities of Entrants ${ }^{17}$

\begin{tabular}{|c|c|c|c|}
\hline \multirow{2}{*}{ Country } & \multicolumn{3}{|c|}{ Duration (Years) } \\
& $\mathbf{2}$ & $\mathbf{4}$ & $\mathbf{7}$ \\
\hline Finland & 52,53 & 42,42 & 29,58 \\
\hline United Kingdom & 57,62 & 42,37 & 33,01 \\
\hline Canada & 68,00 & 50,00 & 35,00 \\
\hline Portugal & 72,07 & 60,39 & 49,34 \\
\hline Italy & 73,10 & 59,46 & 43,92 \\
\hline United States & 73,19 & 56,20 & 42,37 \\
\hline France & 75,47 & 57,66 & 48,20 \\
\hline
\end{tabular}

According to the OECD data about $25 \%$ to $50 \%$ of entering firms fail within the first two and about $40 \%$ to $60 \%$ within the first four years of operation.

Statistics Canada provides a very detailed survey of survival probabilities of all Canadian firms with at least one employee that entered commercial industries over the 1984-1994 period. ${ }^{18}$ The results of this survey are reported in Table 4.

Table 4: Survival and Hazard Rates of Commercial Industries in Canada ${ }^{19}$

\begin{tabular}{|c|c|c|}
\hline Duration (Years) & Survival Rate & Hazard Rate \\
\hline 1 & 0.77 & 0.23 \\
\hline 2 & 0.61 & 0.22 \\
\hline 3 & 0.50 & 0.18 \\
\hline 4 & 0.42 & 0.16 \\
\hline 5 & 0.36 & 0.14 \\
\hline 6 & 0.31 & 0.13 \\
\hline 7 & 0.27 & 0.12 \\
\hline 8 & 0.24 & 0.11 \\
\hline 9 & 0.22 & 0.10 \\
\hline 10 & 0.20 & 0.10 \\
\hline 11 & 0.18 & 0.10 \\
\hline
\end{tabular}

\footnotetext{
${ }^{17}$ Source: OECD (2001). Dates refer to average survival rates estimated for different cohorts of firms that entered the Manufacturing and the Business Service Sector.

Data for the United Kingdom only refer to the Manufacturing Sector and to cohorts of firms that entered the market in the 1985-1990 period.

${ }^{18}$ See Baldwin, J. et al (2000).

The used database is the Longitudinal Employment Analysis Program (LEAP), which is a company-level database that includes all employers in Canada. It tracks the employment and payroll characteristics of individual firms from their year of entry to their year of exit.

${ }^{19}$ Source : Baldwin, J. et al (2000).
} 
The survival rates give the probability that a new firm will live beyond a certain age and the hazard rates represent the likelihood of failure at a particular age. For instance, a Canadian firm has a likelihood of $61 \%$ to survive beyond its second year, and just prior to its third year it has a $18 \%$ likelihood of failing during that third year. It is striking that the probability of a firm completing its first decade is only $20 \%$. Of course, one has to take into account that firms may cease to exist because of takeovers or simply because a venture was only planned for a limited period of time right from the start.

Summing up, it can be stressed that the probability of new firms surviving at least seven years is just between $27 \%$ and $49 \%$ in the countries and time periods we have looked at. This process of entry and failure is very costly for an economy. One may view this process as an investment needed in market economies to discover consumers' demand, or as an investment in managerial experience since unsuccessful entrepreneurs may learn from their experience and do better next time. But the large percentage of entrants that exit the market after only a few years of operation focuses attention on the question of whether too many firms with low probabilities of success enter the market. It will be shown in the next section that adverse selection problems due to asymmetric information on capital markets may explain why there is more entrepreneurial entry than is socially efficient.

\section{Entrepreneurial Entry and Capital Market Imperfections}

As mentioned above, entrepreneurs often face considerable difficulties to achieve outside funds for the financing of their projects. These difficulties are often seen as an important justification of government intervention to support entrepreneurial entry. ${ }^{20}$ The following analysis develops a simple theoretical model to explore whether this view is appropriate. In the following, we only present the most important features of the model in the text whereas most of the formal analysis is performed in the appendix. In our model, individuals may choose between becoming an entrepreneur and working as an employee. If they work as employees, they earn an after tax wage of $w(1-t)$ with certainty, where $w$ is the wage rate, which is assumed to be given exogenously, and $t$ is the personal income tax rate. If they decide to become entrepreneurs, they have to raise funds in order to finance their projects. Each potential entrepreneur is endowed with a project which requires an investment $\mathrm{K}$. If the project turns out to be successful, it produces an output $F(K)$. If it is unsuccessful, the output

\footnotetext{
${ }^{20}$ For instance, Gale $(1990,188)$ argues that "with asymmetric information the market will not fund all socially efficient projects".
} 
is zero. Projects differ only by their probability of success, which is denoted by $\varepsilon_{\mathrm{i}}$. For the economy as a whole, the probability of success is distributed in the interval $[0,1]$, i.e. the worst projects fail with certainty and the best projects never fail.

What determines the amount of entrepreneurial entry in the economy? A household will decide to become an entrepreneur if the expected profit from carrying out the project is at least as high as the income when working as an employee. The marginal entrepreneur is the household who is just indifferent between becoming an entrepreneur and working as an employee. Assume that the after tax profit in the case where the project is successful is given by $\pi(1-\tau)$, where $\tau$ is the profit tax rate. In the following, we will refer to this tax as the corporate income tax rate as opposed to the personal income tax rate which is the tax rate levied on income when working as an employee. The success probability of the marginal entrepreneur $\left(\varepsilon^{\mathrm{m}}\right)$ is given by

$\varepsilon^{\mathrm{m}} \pi(1-\tau)=\mathrm{w}(1-\mathrm{t})$

All households with success probabilities of at least $\varepsilon^{\mathrm{m}}$ will decide to become entrepreneurs while the households with lower success probabilities prefer to work as employees. Equation (1) shows that the amount of entrepreneurial entry depends on the expected profit $\pi$ and the relationship between the corporate and personal income tax rates. In the absence of market failures and taxes, it is easy to show that the entry decisions taken by households are efficient for the economy as a whole. In this case, the success probability of the marginal entrepreneur is given $b^{21}$

$$
\varepsilon^{*} \mathrm{~F}(\mathrm{~K})-(1+\rho) \mathrm{K}=\mathrm{w}
$$

where $\rho$ is the opportunity cost of investment, which may be interpreted, for instance, as the interest rate in the international capital market. Entrepreneurial entry is efficient if the expected output minus the opportunity cost of investment equals the wage rate the entrepreneur could have earned when working as an employee.

\footnotetext{
${ }^{21}$ For the derivation see appendix A.
} 
In the presence of informational asymmetries in the capital market, entrepreneurial entry decisions of households are not necessarily efficient from the perspective of the economy as a whole, i.e. $\varepsilon^{\mathrm{m}}$ may differ from $\varepsilon^{*}$. The expected profit $\pi$ will in general depend on the cost of raising funds from outside investors, and these costs will be affected by informational asymmetries, so that entrepreneurial entry decisions are distorted. In our model, the government may correct these distortions by adjusting the ratio $(1-\tau) /(1-t)$. If the capital market imperfection leads to too little entrepreneurial entry, the government may correct for this by reducing the corporate income tax below the personal income tax and vice versa.

In the following, we assume that the capital market suffers from the following informational asymmetry: Each entrepreneur is fully informed about the specific success probability of his/her project. Outside investors cannot observe firm specific success probabilities. They only know the distribution of the success probabilities for the economy as a whole.

The implications of this informational asymmetry for entrepreneurial entry in this model depend on the type of financing which is available to entrepreneurs and also on the question of whether outside investors can acquire additional information by project screening, which is assumed to be costly. We begin with the case of debt financing without screening and then extend the analysis by allowing for costly screening and equity financing.

\subsection{Debt Financing Without Screening}

Assume that debt is the only source of finance and no signal for firm specific project quality is available. We assume that debt financing is provided by a competitive banking sector, i.e. banks make zero profits in equilibrium. Banks cannot discriminate between projects and therefore offer a standard debt contract with a uniform interest rate which we denote by $\mathrm{r}$. This interest rate is based on the average success probability in the pool of projects which are carried out. Entrepreneurs will carry out their project if their expected after tax profits are at least as high as their after tax income from working as an employee. The success probability of the marginal project under debt financing, which we denote by $\varepsilon^{\mathrm{p}}$, is given by

$$
{ }_{\varepsilon} \mathrm{p}\left[\mathrm{F}(\mathrm{K})-\left(1+\mathrm{r}^{\mathrm{p}}\right) \mathrm{K}\right](1-\tau)=\mathrm{w}(1-\mathrm{t})
$$


Comparing (3) to (1) shows that, at $\tau=t$, entrepreneurial entry would be efficient $\left(\varepsilon^{p}=\varepsilon^{*}\right)$ if $\varepsilon^{\mathrm{p}}\left(1+\mathrm{r}^{\mathrm{p}}\right)=1+\rho$, i.e. if the interest rate charged by the bank reflected project specific risk. But since banks cannot observe project specific risk, $\mathrm{r}^{\mathrm{P}}$ will only reflect average risk. Since the success probability of the marginal entrepreneur is by definition lower than the average success probability of all entrepreneurs who receive loans, we have $\varepsilon^{\mathrm{p}}\left(1+\mathrm{r}^{\mathrm{p}}\right)<1+\rho$, which implies that the interest rate charged to the marginal entrepreneur is inefficiently low. As a consequence, the number of entrepreneurs entering the market is inefficiently high. What is the optimal tax policy in this framework?

\section{Result 1:}

If debt financing without screening is the only source of finance, the optimal labour income tax rate is lower than the corporate income tax rate. ${ }^{22}$

Given that too many entrepreneurs carry out their projects relative to the first best allocation, the result in result 1 is intuitive. By reducing the labour income tax below the corporate income tax, the government induces entrepreneurs with low quality projects to choose the option of working as an employee. Entrepreneurs with better success probabilities will carry out their projects despite the tax disadvantage. It thus turns out that, the optimal policy discourages entrepreneurial entry rather than supporting it.

\subsection{Debt Financing With Screening}

We now extend the analysis by assuming that, in addition to debt financing as described in the preceding section, entrepreneurs can have their project screened by banks. Screening has the advantage of allowing outside investors to observe the specific survival probability of a project. This implies that they will offer debt contracts where the interest rate reflects the project specific success probability. However, this advantage comes at a cost. The screening of projects is a complicated and time consuming task. Entrepreneurs who decide to carry out their projects may now choose between debt financing with or without screening. Screening is an interesting option for entrepreneurs with higher than average success probabilities. If

\footnotetext{
${ }^{22}$ Proof: See appendix B.
} 
screening was costless, the market for unscreened debt would eventually disappear as the more productive firms leave the market. The existence of a positive screening cost implies that both debt markets may coexist. Denote the success probability of an entrepreneur who is indifferent between screened and unscreened debt financing by $\varepsilon^{s}$. While all entrepreneurs with a success probability bigger than $\varepsilon^{s}$ will finance their investment with screened debt, entrepreneurs with smaller success probabilities than $\varepsilon^{s}$ will either use unscreened debt or not carry out the project. Denote the success probability of an entrepreneur who is indifferent between using unscreened debt to finance his project and working as an employee by $\varepsilon^{p s}$. The interest rate for screened debt, $r$, depends on the specific success probability $\varepsilon^{s}$ of the screened entrepreneur $\left(\mathrm{r}\left(\varepsilon^{s}\right)\right)$. The interest rate in the market for unscreened debt $r^{p s}$ is based, as before, on the mean survival probability in this market. Figure 1 illustrates the equilibrium that arises in the margket for debt.

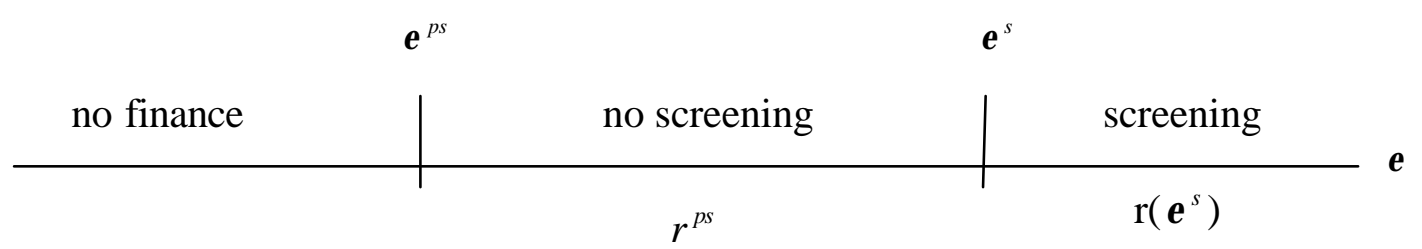

Figure 1: Success probabilities and interest rates with a screening opportunity

What is the implication of the screening option for the efficiency of entrepreneurial entry? Screening reduces the average success probability of unscreened projects relative to the case where screening is not available. As a consequence, the implicit subsidy to the marginal project is smaller, but as long as the market for unscreened debt does not vanish, there is still too much entrepreneurial entry in a laisser faire equilibrium. What does this imply for tax policy?

\section{Result 2:}

If entrepreneurs may choose between screened and unscreened debt to finance their projects, a reduction of the labour income tax rate below the corporate income tax rate reduces entrepreneurial entry, reduces screening and raises welfare. ${ }^{23}$

\footnotetext{
${ }^{23}$ Proof: See appendix C.
} 
Reducing the labor income tax below the corporate income tax rate now has two positive effects. Firstly, entrepreneurs with low success probabilities leave the market, which raises welfare for the reasons discussed in the preceding section. In addition, screening is reduced because the exit of low quality projects improves the average project quality in the market for unscreened debt. Given the number of entrepreneurial projects which are carried out, a reduction of screening is desirable because screening is costly. For the marginal screened firm, entering the pool of unscreened firms is not worthwhile because the benefit to the firm in the form of reduced screening cost would be offset by the fact the firm has to pay an interest rate based on the average success probability of unscreened firms. For the economy as a whole, however, no additional costs would arise if the marginal firm enters the market for unscreened debt. What the individual firm perceives as a cost is actually a redistributive effect. By entering the market for unscreened debt, the firm improves the average quality of the firms in this market and thus marginally reduces the interest rate. The problem is that, due to the existing informational asymmetry, the marginal firm cannot internalize this benefit since all firms pay the reduced interest rate.

\subsection{The Role of Equity Financing}

We have assumed so far that entrepreneurs can only use debt financing. In this section, we extend the analysis by allowing firms to use equity financing. We consider the case where entrepreneurs sell a share of the firm's equity which allows them to finance the initial investment. ${ }^{24}$ Equity investors are assumed to be holding companies endowed with capital that may either be invested in equity or in other financial assets which offer the risk-free rate of return $\rho$. To exclude the problem of incomplete loss offset, we assume that the initial equity investment $\mathrm{K}$ may be deducted for tax purposes from the profits of the holding companies, so that there is no tax deduction at the level of the firm issuing the equity (see appendix D). The holding companies will purchase equity shares of entrepreneurs if the expected profits of this investment are at least as high as the after tax profits that the holding companies receive by investing in safe financial assets. The expected profits are once again based on the average success probability of all firms ssuing equity. This implies that the result of too much entrepreneurial entry also holds for the case of equity financing.

\footnotetext{
${ }^{24}$ One may ask whether firms would not want to sell the entire firm in the equity market. The problem is that selling more equity than what is required to finance $\mathrm{K}$ would be a bad signal to the equity market. It is straightforward to show that the equilibrium is one where all entrepreneurs only sell equity with value K.
} 


\section{Result 3:}

If entrepreneurs finance their investment through equity financing, a reduction of the labour income tax rate below the corporate income tax rate, departing from an equilibrium with no tax distortion, reduces entrepreneurial entry and increases welfare. ${ }^{25}$

The explanation for result 3 is equivalent to that of result 1 , where firms used unscreened debt financing. The shares of firms with low success probabilities are overpriced in the equity market, so that there is a subsidy to entrepreneurs with low productivity projects. By reducing the labour income tax below the corporate income tax, the government may neutralize this subsidy and reduce the entry of low productivity firms.

\section{The possibility of credit rationing}

So far it was assumed that, despite asymmetric information in project quality all entrepreneurial projects do get funded if entrepreneurs are willing to pay sufficiently high risk premia. But it is well known that informational asymmetries may also lead to credit rationing (Stiglitz and Weiss, 1981). In this section, we consider the implications of the Stiglitz-Weiss argument for entrepreneurial entry.

We now assume that projects differ not only by their probability of success but also in their productivity if they are successful. Projects which are very risky, i.e. projects with a low probability of success, also generate very high profits if they are successful. As in Stiglitz and Weiss (1981) all projects have the same expected return ex ante. We also assume in this section that first best entrepreneurial entry requires that all projects under consideration are carried out. This implies that an inefficiency emerges when the projects of some entrepreneurs do not get funded.

\footnotetext{
${ }^{25}$ Proof: See appendix D.
} 


\subsection{Credit Rationing in the Case of Unscreened Debt Financing}

Consider first the case where unscreened debt is the only source of finance for entrepreneurs. The characteristic of the marginal entrepreneur is still that his expected return of starting a new business and his wage income when working as an employee are the same. But while the expected output now remains constant when the success probability changes, the probability of debt default rises with a decrease in the success probability. This implies that entrepreneurs with success probabilities higher than that of the marginal entrepreneur will not carry out their project since they have a rather high probability of paying back the debt and therefore a rather low expected profit. Thus, the marginal entrepreneur is now the one with the highest success probability of all projects getting funded.

It is a well know property of the Stiglitz-Weiss model that the interest rate charged by banks will affect the average success probability of all projects financed. An increase in the interest rate will induce the entrepreneurs with the highest success probabilities to leave the market. The average success probability of the project pool will therefore decline with a rise in the interest rate. Banks take this adverse selection effect into account when setting the interest rate. $^{26}$

Now there are two possible equilibria in the market for debt. If the success probabilities of the entrepreneurs seeking capital are so low that banks' expected revenues from giving loans to entrepreneurs is less than the secure investment, banks would make losses and a situation with complete credit rationing would arise.This may occur because banks will not be able to deal with increasing risks of default by raising the interest rates charged on loans. The increase in the interest rate would only induce the low risk projects to leave the market. This adverse selection effect reduces the expected revenue for the bank and may overcompensate the effect of the higher interest rate. In this case, no project would be financed and the government may raise welfare by creating tax incentives for more entrepreneurial entry. If the corporate tax rate is reduced below the labour income tax rate, more entrepreneurs are willing to enter the market at a given interest rate and the average success probability in the credit portfolio would improve, so that, at some point of tax difference, credit rationing may vanish and some entrepreneurs enter the market.

\footnotetext{
${ }^{26}$ Proof: see appendix E.
} 
In contrast, if the expected revenue from giving credits to entrepreneurs is higher than the secure investment, competition among banks would imply that all banks make zero profits. In this case, some but not all entrepreneurs carry out their projects. All entrepreneurs with a success probability which is below that of the marginal entrepreneur will carry out the project. The resulting equilibrium is characterized by too little entrepreneurial entry, i.e. some entrepreneurs with low risk projects prefer to become employees. In this case, it is again welfare enhancing to reduce the corporate tax rate below the labour income tax rate in order to increase entrepreneurial entry.

The results derived so far in this section can be summarized as:

\section{Result 4:}

If projects differ in risk but have the same expected returns, and if unscreened debt is the only source of finance for entrepreneurs, a reduction of the corporate income tax rate below the labour income tax rate increases entrepreneurial entry and raises welfare. ${ }^{27}$

The market failure which explains result 4 may again be explained by considering the entrepreneurial entry decision of the marginal firm. The marginal firm does not take into account that, by entering the credit market, it improves the average success probability in the pool of firms asking for credits. However, since all firms face the same credit contract, the benefit of this improvement is distributed to all firms, i.e. the marginal firm entering the market now exerts a positive externality for all other firms. This explains why, in the equilibrium without government intervention, there is too little entrepreneurial entry.

\subsection{Credit Rationing in the Case of Screened Debt and Equity Financing}

Result 4 contradicts our earlier findings in section 4, according to which there was a tendency for too much entrepreneurial entry. However, a limitation of the result in result 4 is that it no longer holds if either project screening or equity financing is allowed. In this sense, equity financing dominates debt financing in this setting since equity financing does not imply any screening costs.

\footnotetext{
${ }^{27}$ Proof: see appendix F.
} 
Consider first the problem of equity financing. If entrepreneurs can sell their firm in the equity market, the problem of asymmetric information vanishes because all firms have the same expected return. But it should be noticed that some entrepreneurs, especially those with very small start ups, might have difficulties in raising equity.

Consider next the possibility of screening. If banks can screen projects at a certain cost per unit of funds invested, two equilibria may arise. Firstly, it is possible that some projects are financed via unscreened debt but that no screening takes place. This equilibrium would arise if the expected revenue from the marginal entrepreneur, i.e. the entrepreneur with the highest success probability, is higher in the case of unscreened debt than in the case of screened debt. The possibility of screening would then be irrelevant for all entrepreneurs because screening is too costly.

The second possible equilibrium is one where it is profitable for entrepreneurs with high success probabilities to choose the screening option, i.e. their expected return from starting a new business is higher than working as an employee even when the interest rate reflects the screening costs. In this situation all projects would be carried out since all entrepreneurs with low risks would let banks screen their projects. Thus, the case for subsidizing entrepreneurial entry vanishes. These results may be summarized as

\section{Result 5:}

If projects differ in risk but have the same expected returns, and if entrepreneurs may finance their projects either through screened debt or equity, tax incentives cannot improve the efficiency of entrepreneurial entry. ${ }^{28}$

\section{The efficiency of project screening}

So far, our analysis has shown that screening may significantly affect the level of entrepreneurial entry and the efficiency of the equilibrium. This raises the question whether the level of screening under laisser faire is efficient. Consider first the variant of the model developed in section 3, where projects differ in their expected return. High quality firms are willing to bear the cost of screening because screening allows them to receive loans at lower

\footnotetext{
${ }^{28}$ Proof: see appendix G.
} 
interest rates. Why could this be inefficient for the economy as a whole? Consider a firm which is just indifferent between screening and no screening. It has been shown in section 4.2 that the project quality of this firm is marginally higher than that of the best projects in the pooling market. For this firm, the benefit of entering the pooling market would be that the screening cost can be avoided. The cost is that the firm has to pay an interest rate which is based on average project quality in the pooling market, which is lower than the project quality of this specific firm. The problem is that, what the individual firm perceives as a cost of entering the pooling market is only a redistributive effect for the economy as a whole. Since the firm improves average quality in the pooling market, all firms in this market benefit if the firm switches from the screening to the pooling market. Individual firms do not take into account this positive externality of entering the pooling market, so that there is too much screening, given the overall number of projects.

But there is a further effect of screening which has to be taken into account. If more firms choose the screening option, average project quality in the pooling market declines and interest rates increase. This drives some low quality projects out of the market, i.e. the marginal entrepreneurs will not carry out their projects. Since these projects are innefficient for the economy as a whole, this is a positive effect of screening. Again, individual firms do not take this into account when deciding for or against project screening. So the question arises whether this positive effect of screening may outbalance the negative effect of screening described above, i.e. whether there is too much or too little screening. In general, this depends on how firms are distributed over project quality. But if we assume that there is a uniform distribution if firms over project quality, it turns out that the tendency towards too much screening prevails, so that a case can be made for taxes on screening activities:

\section{Result 6}

If firms are uniformly distributed over project quality, introducing a tax on screening increases welfare. $^{29}$

Of course, result 6 cannnot easily translated into policy conclusions because, even if one accepts the herioc assumption of a uniform distribution of firms over project quality, it is probably impossible to design a tax which distiguishes between screening expenditures and

\footnotetext{
${ }^{29}$ Proof: See appendix H.
} 
other activities of banks. Moreover, there are several additional aspects of screening which should be taken into account but are not covered by our analysis so far. One important issue is the fact that screening is likely to be imperfect. If screening only produces an imperfect signal about project quality, the result that there is too much screening may be reversed. Boadway and Sato (1999) consider a model with two types of project quality and costly screening, where a higher screening intensity reduces the probability of screening errors. It turns out that the screening intensity may also be too low.

Finally, the analysis does not take into account that screening activities are typically linked to consulting, which implies that screening may be considered as productive. For instance, one could assume that screening not only reveeals information but also increases the success probability of screened projects. Here, the question arises whether banks (or venture capitalists) have sufficient incentives to engage in costly but productive screening activities. In a model with two sided moral hazard but without adverse selection, Keuschnigg and Nielsen (2002) show that there will be a tendency towards too little screening (or consulting effort).

\section{Conclusions}

Our analysis has focused on the distortions of entrepreneurial entry decisions in the presence of capital market imperfections and the role of tax policy as a corrective device. We have shown that, under different assumptions on the available sources of finance, adverse selection problems in capital markets lead to too much rather than too little entrepreneurial entry. The only exception is the case discussed in section 5, where credit rationing may occur or low risk projects leave the market. However, this result is not very robust. It has been shown that the case for subsidizing entrepreneurial entry vanishes in this case if equity financing or screening is taken into account. Our analysis thus suggests that arguments in favour of subsidizing entrepreneurial entry cannot easily be based on the observation that new firms, which need outside finance, face poorly informed outside investors.

We have also considered the question whether there is too much or too little project screening. In our model there is a tendency towards too much screening, despite the fact that an increase in screening activities drives low quality projects out of the market. But if additional considerations external the simple model we use, are taken into account, such as imperfect 
screening or productive effects of screening, the result that there is too much screening is called into question. Given this, the best policy may be not to intervene in private screening activities.

One should also note that our analysis does not dismiss subsidies for entrepreneurial entry in general. As mentioned in the introduction, the analysis of this paper focuses on problems of asymmetric information in the capital market for start-up firms and abstracts from other potential justifications of subsidies for entrepreneurs, such as positive externalities of firm formation or the positive impact of entrepreneurship on labour market performance.

\section{Appendix}

\section{Notation for Appendices A-H}

$\mathrm{K} \quad$ : investment required by each project (exogenous)

$\mathrm{F}(\mathrm{K}) \quad$ : output if project is successful

$\varepsilon \quad:$ success probability, which is distributed in the interval $[0,1]$

$\mathrm{g}(\varepsilon) \quad$ : density function (continuous) of success probability

$\mathrm{G}(\varepsilon)$ : distribution function of success probability

w : wage income (exogenous)

$\rho \quad$ : risk-free interest rate

$\tau \quad$ : corporate income tax rate

$\mathrm{t}$ : labor income tax rate

c : screening costs per unit of capital K

\section{Appendix A}

If potential entrepreneurs with a success probability of at least $\varepsilon^{*}$ carry out the project, overall welfare $\mathrm{W}$ is given by

$$
\mathrm{W}=\int_{\varepsilon^{*}}^{1}[\varepsilon \mathrm{F}(\mathrm{K})-(1+\rho) \mathrm{K}] \mathrm{g}(\varepsilon) \mathrm{d} \varepsilon+\int_{0}^{\varepsilon^{*}} \mathrm{wg}(\varepsilon) \mathrm{d} \varepsilon
$$

The optimal level of entrepreneurial entry is thus given by

$$
\frac{\partial \mathrm{W}}{\partial \varepsilon^{*}}=-\left[\varepsilon^{*} \mathrm{~F}(\mathrm{~K})-(1+\rho) \mathrm{K}-\mathrm{w} \operatorname{gg}\left(\varepsilon^{*}\right)=0\right.
$$

which implies

$$
\varepsilon^{*} \mathrm{~F}(\mathrm{~K})-(1+\rho) \mathrm{K}=\mathrm{w},
$$

Q.E.D. 


\section{Appendix B}

Denote $\mathrm{r}^{\mathrm{p}}$ as the uniform interest rate offered by banks and $\varepsilon^{\mathrm{p}}$ as the survival probability of the marginal firm. $\varepsilon^{\mathrm{p}}$ is given by:

$$
\varepsilon^{\mathrm{p}}\left[\mathrm{F}(\mathrm{K})-\left(1+\mathrm{r}^{\mathrm{p}}\right) \mathrm{K}\right](1-\tau)=\mathrm{w}(1-\mathrm{t})
$$

${ }_{\mathrm{r}}^{\mathrm{p}}$ must satisfy (zero profit condition):

$$
\varepsilon^{\mathrm{p}+}\left(1+\mathrm{r}^{\mathrm{p}}\right)-(1+\rho)=0
$$

where $\varepsilon^{\mathrm{p}+}$ is the mean of the survival probability of all firms issuing debt

$$
\varepsilon^{\mathrm{p}+}=\frac{1}{\left(1-\mathrm{G}\left(\varepsilon^{\mathrm{p}}\right)\right)} \int_{\varepsilon}^{1} \varepsilon \mathrm{p}(\varepsilon) \mathrm{d} \varepsilon
$$

Substituting (B.1) into (B.2) yields (with $\beta=\frac{(1-t)}{(1-\tau)}$ )

$$
\varepsilon^{p} F(K)-\frac{\varepsilon^{p}}{\varepsilon^{p+}}(1+\rho) K=w \beta
$$

Reducing t below $\tau$ implies an increase in $\beta$. Equation (B.4) implies $\frac{d \varepsilon^{p}}{d \beta}>0$. The marginal effect of an increase in $\varepsilon^{\mathrm{p}}$ on welfare, evaluated from $\beta=1$, is

$$
\frac{\partial W}{\partial \varepsilon^{p}}=-\left[\varepsilon^{p} F(K)-(1+\rho) K-w\right] g\left(\varepsilon^{p}\right)
$$

Substituting (B.4) into (B.5) yields

$$
\frac{\partial W}{\partial \varepsilon^{p}}=\left(1-\frac{\varepsilon^{p}}{\varepsilon^{p+}}\right)(1+\rho) K g\left(\varepsilon^{p}\right)>0 .
$$

Q.E.D.

\section{Appendix C}

$\varepsilon^{\mathrm{s}}$ is given by:

$$
\varepsilon^{\mathrm{S}}\left[\mathrm{F}(\mathrm{K})-\left(1+\mathrm{r}\left(\varepsilon^{\mathrm{S}}\right)\right) \mathrm{K}\right](1-\tau)=\varepsilon^{\mathrm{S}}\left[\mathrm{F}(\mathrm{K})-\left(1+\mathrm{r}^{\mathrm{ps}}\right) \mathrm{K}\right](1-\tau)
$$

$\varepsilon^{\mathrm{ps}}$ is given by

$$
\varepsilon^{\mathrm{ps}}\left[\mathrm{F}(\mathrm{K})-\left(1+\mathrm{r}^{\mathrm{ps}}\right) \mathrm{K}\right]=\mathrm{w} \beta \text {. }
$$

Given that banks make zero profits, the interest rates $r\left(\varepsilon^{\mathrm{S}}\right)$ and $\mathrm{r}^{\mathrm{ps}}$ are given by 


$$
1+r\left(\varepsilon^{\mathrm{s}}\right)=\frac{(1+\rho)(1+\mathrm{c})}{\varepsilon^{\mathrm{s}}}
$$

and

$$
1+\mathrm{r}^{\mathrm{ps}}=\frac{1+\rho}{\varepsilon^{\mathrm{ps}+}}
$$

where

$$
\varepsilon^{\mathrm{ps}+}=\frac{1}{\left(\mathrm{G}\left(\varepsilon^{\mathrm{s}}\right)-\mathrm{G}\left(\varepsilon^{\mathrm{ps}}\right)\right)} \int_{\varepsilon^{\mathrm{ps}}}^{\varepsilon^{\mathrm{s}} \varepsilon \mathrm{g}(\varepsilon) \mathrm{d} \varepsilon}
$$

is the mean of the survival probability of firms in the market for unscreened debt.

Using (C.3) and (C.4), (C.1) can be written as

$1+\mathrm{c}=\frac{\varepsilon^{\mathrm{s}}}{\varepsilon^{\mathrm{ps}+}}$

and (C.2) becomes

$$
\varepsilon^{\mathrm{ps}} \mathrm{F}(\mathrm{K})-\frac{\varepsilon^{\mathrm{ps}}}{\varepsilon^{\mathrm{ps}+}}(1+\rho) \mathrm{K}=\mathrm{w} \beta \text {. }
$$

(C.7) and (C.6) can be written as

$$
\mathrm{A}\left(\varepsilon^{p s}, \varepsilon^{s}, \beta\right) \equiv \varepsilon^{p s} F(K)-\frac{\varepsilon^{p s}}{\varepsilon^{p s t}}(1+\rho) K-w \beta=0
$$

and

$$
\mathrm{B}\left(\varepsilon^{\mathrm{ps}}, \varepsilon^{\mathrm{s}}, \beta\right) \equiv \frac{\varepsilon^{\mathrm{s}}}{\varepsilon^{\mathrm{ps}+}}-(1+\mathrm{c})=0
$$

Differentiating (C.8) and (C.9) using Cramer's rule yields

$$
\frac{d \varepsilon^{p s}}{d \beta}=-\frac{1}{\Xi} \frac{\partial \mathrm{A}}{\partial \beta} \frac{\partial \mathrm{B}}{\partial \varepsilon^{s}}>0
$$

and

$$
\frac{d \varepsilon^{s}}{d \beta}=\frac{1}{\Xi} \frac{\partial \mathrm{A}}{\partial \beta} \frac{\partial \mathrm{B}}{\partial \varepsilon^{p s}}>0
$$

where

$\Xi=\frac{\partial \mathrm{A}}{\partial \varepsilon^{p s}} \frac{\partial \mathrm{B}}{\partial \varepsilon^{s}}-\frac{\partial \mathrm{A}}{\partial \varepsilon^{s}} \frac{\partial \mathrm{B}}{\partial \varepsilon^{p s}}>0$.

Overall welfare is now given by

$$
\mathrm{W}=\mathrm{n} \int_{\varepsilon^{\mathrm{s}}}^{1}[\varepsilon \mathrm{F}(\mathrm{K})-(1+\rho)(1+\mathrm{c}) \mathrm{K}] \mathrm{g}(\varepsilon) \mathrm{d} \varepsilon+\mathrm{n} \int_{\varepsilon^{\mathrm{ps}}}^{\varepsilon^{\mathrm{s}}}[\varepsilon \mathrm{F}(\mathrm{K})-(1+\rho) \mathrm{K}] \mathrm{g}(\varepsilon) \mathrm{d} \varepsilon+\mathrm{n} \int_{0}^{\varepsilon^{\mathrm{ps}}} \mathrm{wg}(\varepsilon) \mathrm{d} \varepsilon
$$


Differentiating with respect to $\varepsilon^{\mathrm{ps}}$ and $\varepsilon^{\mathrm{S}}$ yields

$$
\frac{\partial W}{\partial \varepsilon^{p s}}=-n\left[\varepsilon^{p s} F(K)-(1+\rho) K-w\right] g\left(\varepsilon^{p s}\right)
$$

and

$$
\frac{\partial \mathrm{W}}{\partial \varepsilon^{\mathrm{s}}}=\mathrm{nc}(1+\rho) \operatorname{Kg}\left(\varepsilon^{\mathrm{s}}\right)>0
$$

Evaluating (A.8) at $\beta=1$ and using (13) yields

$$
\frac{\partial W}{\partial \varepsilon^{p s}}=n\left(1-\frac{\varepsilon^{p s}}{\varepsilon^{p+}}\right)(1+\rho) K g\left(\varepsilon^{p s}\right)>0
$$

It follows that an increase in $\beta$, departing from $\beta=1$, increases welfare. Q.E.D.

\section{Appendix D}

The equity share required to finance $\mathrm{K}$ is given by

$$
(1+\rho(1-\tau)) \mathrm{K}=\mathrm{s} \varepsilon^{\mathrm{e}+} \mathrm{F}(\mathrm{K})(1-\tau)+\tau \mathrm{K}
$$

where $\varepsilon^{\mathrm{e}+}$ is the mean of the survival probability of all firms issuing equity.

The profit of an entrepreneur issuing equity can thus be written as

$$
(1-\mathrm{s})\left(\varepsilon_{\mathrm{i}} \mathrm{F}(\mathrm{K})(1-\tau)\right)=\left(\varepsilon_{\mathrm{i}} \mathrm{F}(\mathrm{K})-\frac{\varepsilon_{\mathrm{i}}}{\varepsilon^{\mathrm{e}+}}(1+\rho) \mathrm{K}\right)(1-\tau)
$$

Comparing (D.2) to (A.4) shows that the expected profits of entrepreneurs in the cases of unscreened debt financing and equity financing is the same. Q.E.D.

\section{Appendix E}

$\mathrm{p}_{\mathrm{i}} \quad$ : success probability of project i (distributed in $[0,1]$ )

$\gamma\left(\mathrm{p}_{\mathrm{i}}\right)$ : output multiplier (indicates profitability) 
$\gamma\left(\mathrm{p}_{\mathrm{i}}\right) \mathrm{p}_{\mathrm{i}}=1$

The success probability of the indifferent entrepreneur $\mathrm{p}^{\mathrm{n}}$ is given by:

$$
\mathrm{p}^{\mathrm{n}}\left[\gamma\left(\mathrm{p}^{\mathrm{n}}\right) \mathrm{F}(\mathrm{K})-\left(1+\mathrm{r}^{\mathrm{n}}\right) K\right]=w \beta \text {. }
$$

Increase in $\mathrm{r}^{\mathrm{n}}$ leads to an decrease in $\mathrm{p}^{\mathrm{n}}$ :

$$
\frac{d p^{n}}{d r}=-\frac{p^{n}}{1+r^{n}}<0
$$

Being $\mathrm{p}^{-}$the average success probability of all projects financed by a bank, the expected profit of a bank is given by:

$$
\Pi^{\mathrm{B}}=\left(\mathrm{p}^{-}\left(1+\mathrm{r}^{\mathrm{n}}\right)-(1+\rho)\right) \mathrm{K}
$$

The maximum interest rate $\mathrm{r}^{\mathrm{n} \text { max }}$ is determined by:

$$
\frac{\partial \Pi^{B}}{\partial r^{n}}=\frac{\partial p^{-}}{\partial p^{n}} \frac{\partial p^{n}}{\partial r^{n}}\left(1+r^{n}\right)+p^{-}=0
$$

\section{Appendix F}

No project financing:

$$
\mathrm{p}^{-}\left(1+\mathrm{r}^{\mathrm{n} \max }\right)<(1+\rho)
$$

Project financing:

$$
\mathrm{p}^{-}\left(1+\mathrm{r}^{\mathrm{n} \max }\right) \geq(1+\rho)
$$

Due to zero profit condition:

$$
\mathrm{p}^{-}\left(1+\mathrm{r}^{\mathrm{n}}\right)=(1+\rho)
$$

Using (F.3) (E.1) can be written as:

$$
\mathrm{p}^{\mathrm{n}} \gamma\left(\mathrm{p}^{\mathrm{n}}\right) \mathrm{F}(\mathrm{K})-\frac{\mathrm{p}^{\mathrm{n}}}{\mathrm{p}^{-}}(1+\rho) \mathrm{K}=\mathrm{w} \beta
$$

which implies to little entrepreneurial entry since $\left(\frac{p^{n}}{p^{-}}>1\right)$.

Reducing the corporate tax rate below the labour income tax rate (decrease in $\beta$ ) leads to an increase in $\mathrm{p}^{\mathrm{n}}$ (more entrepreneurs with low risk projects enter the market):

$$
\frac{\mathrm{dp}}{\mathrm{d} \beta}=-\frac{\mathrm{w}}{1+\mathrm{r}^{\mathrm{n}}}<0
$$

Q.E.D.

\section{Appendix G:}

The interest rate of a screened project $\mathrm{r}^{\mathrm{ns}}$ with success probability $\mathrm{p}_{\mathrm{j}}$ is given by: 


$$
\mathrm{p}_{\mathrm{j}}\left(1+\mathrm{r}^{\mathrm{ns}}\right)=(1+\rho)(1+\mathrm{c})
$$

The expected profit of an entrepreneur with a screened project is simply:

$$
F(K)-(1+\rho)(1+c) K
$$

There is an equilibrium without screening if:

$$
\mathrm{F}(\mathrm{K})-\frac{\mathrm{p}^{\mathrm{n}}}{\mathrm{p}^{-}}(1+\rho) \mathrm{K}=\mathrm{w} \beta>\mathrm{F}(\mathrm{K})-(1+\rho)(1+\mathrm{c}) \mathrm{K}
$$

There is an equilibrium with screening if $F(K)-(1+\rho)(1+c) K \geq w \beta$. In this case, entrepreneurs with success probability $\mathrm{p}_{\mathrm{j}} \geq \mathrm{p}^{\mathrm{ns}}$ choose the screening option and all projects are carried out. $\mathrm{p}^{\mathrm{ns}}$ is given by:

$$
(1+c)=\frac{p^{n s}}{p^{-}}
$$

Given that all projects are carried out, no efficiency improvements through taxes or subsidies on entry can be achieved.

\section{Appendix H}

Assume that there is a tax on screening expenditures denoted by $\theta$. The equilibrium values of $\varepsilon^{\mathrm{s}}$ and $\varepsilon^{\mathrm{ps}}$ are given by:

$$
\varepsilon^{\mathrm{s}} \mathrm{F}(\mathrm{K})-(1+\mathrm{c}(1+\theta))(1+\rho) \mathrm{K}=\varepsilon^{\mathrm{s}} \mathrm{F}(\mathrm{K})-\frac{\varepsilon^{\mathrm{s}}}{\varepsilon^{\mathrm{ps}+}}(1+\rho) \mathrm{K}
$$

and

$$
\varepsilon^{\mathrm{ps}} \mathrm{F}(\mathrm{K})-\frac{\varepsilon^{\mathrm{ps}}}{\varepsilon^{\mathrm{ps}+}}(1+\rho) \mathrm{K}=\mathrm{w} \beta
$$

Uniform distribution of entrepreneurs over success probabilities implies

$$
\varepsilon^{p s+}=\frac{\varepsilon^{\mathrm{s}}+\varepsilon^{\mathrm{ps}}}{2}
$$

Thus (H.1) and (H.2) can be written as

$$
A\left(\varepsilon^{s}, \varepsilon^{p s}, \theta\right) \equiv 1+c(1+\theta)-\frac{2 \varepsilon^{s}}{\varepsilon^{s}+\varepsilon^{p s}}=0
$$

and

$$
B\left(\varepsilon^{s}, \varepsilon^{p s}, \theta\right) \equiv \varepsilon^{p s} F(K)-\frac{2 \varepsilon^{p s}}{\varepsilon^{s}+\varepsilon^{p s}}(1+\rho) K-w \beta=0
$$


Differentiating (H.4) and (H.5) using Cramer's Rule and evaluating for $\theta=0$ and $\beta=1$ yields:

$$
\begin{aligned}
& \frac{d \varepsilon^{s}}{d \theta}=-\frac{c}{\Delta}\left(F(K)-\frac{2 \varepsilon^{s}}{\left(\varepsilon^{\mathrm{s}}+\varepsilon^{p s}\right)^{2}}(1+\rho) K\right)>0 \\
& \text { since } F(K)-\frac{2}{\varepsilon^{\mathrm{s}}+\varepsilon^{\mathrm{ps}}}(1+\rho) \mathrm{K}=\frac{1}{\varepsilon^{\mathrm{ps}+}}\left(\varepsilon^{\mathrm{ps}+} \mathrm{F}(\mathrm{K})-(1+\rho) K\right)>0
\end{aligned}
$$

(i.e. the average project in the pooling market generates a positive expected return. Otherwise the entrepreneurs in this market would prefer $\mathrm{w}$ as a payoff)

and

$$
\frac{d \varepsilon^{p s}}{d \theta}=\frac{c}{\Delta}\left(\frac{2 \varepsilon^{p s}}{\left(\varepsilon^{s}+\varepsilon^{p s}\right)^{2}}(1+\rho) K\right)<0
$$

where

$$
\Delta=-\frac{2 \varepsilon^{p s}}{\left(\varepsilon^{s}+\varepsilon^{p s}\right)^{2}} F(K)<0
$$

Overall welfare is now given by:

$W=n \int_{\varepsilon}^{1}[\varepsilon F(K)-(1+\rho+c(1+\rho)) K] g(\varepsilon) d \varepsilon+n \int_{\varepsilon^{s}}^{\varepsilon^{s}}[\varepsilon F(K)-(1+\rho) K] g(\varepsilon) d \varepsilon+n \int_{0}^{\varepsilon^{p s}} w g(\varepsilon) d \varepsilon$ (H.8)

The welfare effect of introducing the tax on screening is

$$
\frac{d W}{d \theta}=\frac{d \varepsilon^{p s}}{d \theta}\left(w-\varepsilon^{p s} F(K)+(1+\rho) K\right)+\frac{d \varepsilon^{s}}{d \theta} c K(1+\rho)
$$

Using (H.4) - (H.7), this yields

Q.E.D.

$$
\frac{d W}{d \theta}=-\frac{c}{\Delta}(1+\rho)^{2} K^{2} \frac{\left(\varepsilon^{s}-\varepsilon^{p s}\right)}{\left(\varepsilon^{s}+\varepsilon^{p s}\right)}\left(F(K)-\frac{2}{\varepsilon^{s}+\varepsilon^{p s}}(1+\rho) K\right)>0
$$

\section{References:}

Almus, M. and Prantl, S. (2001), Die Auswirkungen öffentlicher Gründungsförderung auf das Überleben und Wachstum junger Unternehmen, Mimeo.

Baldwin, J. et al (2000), Failure Rates for new Canadian Firms : New Perspectives on Entry and Exit, Statistics Canada, Catalogue No. 61-526-XIE.

Boadway, R. and M. Sato (1999), Information acquisition and government intervention in credit markets, Journal of Public Economic Theory 1, 283-308.

Bundesministerium für Wirtschaft und Technologie (2000), Action Program - Small and Midsize Enterprsises. 
De Meza, D. and Webb, D. (1987), Too much investment: A problem of asymmetric information, Quarterly Journal of Economics 102, 281-292.

De Meza, D. and Webb, D. (1988), Credit Market Efficiency and Tax Policy in the Presence of Screening Costs, Journal of Public Economics 36, 1-22.

De Meza, D. and Webb, D. (2000), Does credit rationing imply insufficient lending?, Journal of Public Economics 78, 215-234.

European Council (2000), Council Decision (2000/819/EC) of 20 December 2000 on a multiannual programme for enterprise and entrepreneurship, and in particular for small and medium-sized enterprises (SMEs) (2001-2005).

European Commission (2002), The work for the Enterprise Directorate-General. A description of its activities and goals.

Fuest, C. B. Huber and S. B. Nielsen (2000), Why is the corporate tax rate lower than the personal tax rate? EPRU Working Paper 2000-17, forthcoming in: Journal of Public Economics.

Gale, W.G. (1990), Federal lending and the market for credit, Journal of Public Economics 42, 177-193.

Gebhardt, G. and Schmidt, K.M. (2001), Der Markt für Venture Capital: Anreizprobleme, Governance Strukturen und staatliche Interventionen, forthcoming in: Perspektiven der Wirtschaftspolitik.

Gompers, P.A. and Lerner, J. (1999), What drives Venture Capital Fundraising?, NBER Working Paper 6906.

Gordon, R.H. (1998), Can High Personal Tax Rates Encourage Entrepreneurial Activity?, IMF Staff Papers 45, $49-80$.

Holtz-Eakin, D. (2000), Public Policy Toward Entrepreneurship, Small Business Economics $15,283-291$.

Keuschnigg, C. and Nielsen, S. B. (2000), Tax Policy, Venture Capital, and Entrepreneurship, NBER Working Paper 7976.

Keuschnigg, C. and Nielsen, S. B. (2001), Public Policy for Venture Capital, CESifo Working Paper 486.

Keuschnigg, C. and Nielsen, S. B. (2002), Start-ups, Venture Capitalists, and the Capital Gains Tax, Mimeo.

Myers, S.C., Majluf, N.S. (1984), Corporate financing and investment decisions when firms have information that investors do not have. Journal of Financial Economics 13, 187-221.

OECD (2001), OECD Economic Outlook 69.

Reynolds, et al (2001), Global Entrepreneurship Monitor. 2001 Executive Report. 
Romer, D. (1996), Advanced Macroeconomics, Berkeley.

SBA (2001), 47 Years of Service to America's Small Business: The U.S. Small Business Administration 1953-2000.

Stiglitz, J.E. and Weiss, A. (1981), Credit Rationing in Markets with Imperfect Information, The American Economic Review 71, 393 - 410. 


\title{
CESifo Working Paper Series
}

\author{
(for full list see www.cesifo.de)
}

809 Florian Englmaier and Achim Wambach, Contracts and Inequity Aversion, November 2002

810 Sarbajit Sengupta, Delegating Recruitment under Asymmetric Information, December 2002

811 Rajshri Jayaraman, On the Partial Public Provision of a Private Good, December 2002

812 Stéphanie Stolz, Banking Supervision in Integrated Financial Markets: Implications for the EU, December 2002

813 Christian Keuschnigg, Taxation of a Venture Capitalist with a Portfolio of Firms, December 2002

814 Inés Macho-Stadler and David Pérez-Castrillo, Settlement in Tax Evasion Prosecution, December 2002

815 Rainer Niemann and Dirk Simons, Costs, Benefits, and Tax-induced Distortions of Stock Option Plans, December 2002

816 Jan-Egbert Sturm and Barry Williams, Deregulation, Entry of Foreign Banks and Bank Efficiency in Australia, December 2002

817 V. Anton Muscatelli, Patrizio Tirelli, and Carmine Trecroci, Monetary and Fiscal Policy Interactions over the Cycle: Some Empirical Evidence, December 2002

818 Claude Hillinger, A General Theory of Price and Quantity Aggregation and Welfare Measurement, December 2002

819 Erkki Koskela and Ronnie Schöb, Optimal Capital Taxation in Economies with Unionised and Competitive Labour Markets, December 2002

820 Sheilagh Ogilvie, Guilds, Efficiency, and Social Capital: Evidence from German ProtoIndustry, December 2002

821 Hans Gersbach and Verena Liessem, Financing Democracy, December 2002

822 Costas Hadjiyiannis, Panos Hatzipanayotou, and Michael S. Michael, Optimal Tax Policies with Private-Public Clean-Up, Cross-Border Pollution and Capital Mobility, December 2002

823 François Ortalo-Magné and Sven Rady, Homeownership: Low Household Mobility, Volatile Housing Prices, High Income Dispersion, December 2002 
824 Syed M. Ahsan and Panagiotis Tsigaris, Measuring the Social Discount Rate under Uncertainty: A Methodology and Application, December 2002

825 Kai A. Konrad, Altruism and Envy in Contests: An Evolutionarily Stable Symbiosis, December 2002

826 Robert S. Chirinko and Huntley Schaller, A Revealed Preference Approach to Understanding Corporate Governance Problems: Evidence from Canada, December 2002

827 Geir B. Asheim, Green National Accounting for Welfare and Sustainability: A Taxonomy of Assumptions and Results, December 2002

828 Andrea Gebauer, Chang Woon Nam, and Rüdiger Parsche, Lessons of the 1999 Abolition of Intra-EU Duty Free Sales for Eastern European EU Candidates, December 2002

829 Giacomo Corneo, Work and Television, December 2002

830 Vivek H. Dehejia and Yiagadeesen Samy, Trade and Labour Standards - Theory, New Empirical Evidence, and Policy Implications, December 2002

831 Geir B. Asheim and Wolfgang Buchholz, A General Approach to Welfare Measurement through National Income Accounting, December 2002

832 Aaron Tornell and Frank Westermann, The Credit Channel in Middle Income Countries, January 2003

833 Gebhard Flaig, Time Series Properties of the German Monthly Production Index, January 2003

834 Campbell Leith and Jim Malley, Estimated Open Economy New Keynesian Phillips Curves for the G7, January 2003

835 Burkhard Heer and Bernd Süssmuth, Inflation and Wealth Distribution, January 2003

836 Erkki Koskela and Leopold von Thadden, Optimal Factor Taxation under Wage Bargaining - A Dynamic Perspective, January 2003

837 Carola Grün and Stephan Klasen, Growth, Income Distribution, and Well-Being: Comparisons across Space and Time, January 2003

838 Robert S. Chirinko and Ulf von Kalckreuth, On the German Monetary Transmission Mechanism: Interest Rate and Credit Channels for Investment Spending, January 2003

839 Sascha O. Becker, Andrea Ichino, and Giovanni Peri, How Large is the "Brain Drain" from Italy?", January 2003

840 Albert Berry and John Serieux, All About the Giants: Probing the Influences on Growth and Income Inequality at the End of the $20^{\text {th }}$ Century, January 2003 
841 Robert Fenge and Martin Werding, Ageing and the Tax Implied in Public Pension Schemes: Simulations for Selected OECD Countries, January 2003

842 Robert Fenge and Martin Werding, Ageing and Fiscal Imbalances Across Generations: Concepts of Measurement, January 2003

843 Giovanni Andrea Cornia, The Impact of Liberalisation and Globalisation on Income Inequality in Developing and Transitional Economies, January 2003

844 Peter Fredriksson and Per Johansson, Program Evaluation and Random Program Starts, January 2003

845 Bernd Hayo and Matthias Wrede, Fiscal Equalisation: Principles and an Application to the European Union, January 2003

846 Syed M. Ahsan and Jaideep Oberoi, Inequality, Well-being and Institutions in Latin America and the Caribbean, January 2003

847 Chang Woon Nam and Doina Maria Radulescu, The Role of Tax Depreciation for Investment Decisions: A Comparison of European Transition Countries, January 2003

848 V. Bhaskar and Steinar Holden, Wage Differentiation via Subsidised General Training, January 2003

849 Paloma Lopez-Garcia, Labour Market Performance and Start-up Costs: OECD Evidence, January 2003

850 Christian Keuschnigg and Soren Bo Nielsen, Public Policy for Start-up Entrepreneurship with Venture Capital and Bank Finance, January 2003

851 Yin-Wong Cheung, Menzie D. Chinn, and Eiji Fujii, China, Hong Kong, and Taiwan: A Quantitative Assessment of Real and Financial Integration, January 2003

852 Gregory D. Hess, The Economic Welfare Cost of Conflict: An Empirical Assessment, February 2003

853 Douglas J. Cumming and Jeffrey G. MacIntosh, Comparative Venture Capital Governance. Private versus Labour Sponsored Venture Capital Funds, February 2003

854 Eckhard Janeba and John Douglas Wilson, Decentralization and International Tax Competition, February 2003

855 Tapio Palokangas, Capital Accumulation and Employment Cycles in a Model of Creative Destruction, February 2003

856 Brendan Walsh, When Unemployment Disappears: Ireland in the 1990s, February 2003

857 Luis H. R. Alvarez and Erkki Koskela, A General Approach to the Stochastic Rotation Problem with Amenity Valuation, February 2003

858 Christian Schultz, Strategic Campaigns and Redistributive Politics, February 2003 
859 Ernst Fehr and Joseph Henrich, Is Strong Reciprocity a Maladaptation? On the Evolutionary Foundations of Human Altruism, February 2003

860 Haizhou Huang, Dalia Marin, and Chenggang Xu, Financial Crisis, Economic Recovery and Banking Development in Former Soviet Union Economies, February 2003

861 Pedro Cardoso and Bernard M.S. van Praag, How Sustainable Are Old-age Pensions in a Shrinking Population with Endogenous Labour Supply?, February 2003

862 Volker Meier, Efficient Transfer of Aging Provisions in Private Health Insurance, February 2003

863 Edward Castronova, Theory of the Avatar, February 2003

864 Robert S. Chirinko, Hans van Ees, Harry Garretsen, and Elmer Sterken, Investor Protections and Concentrated Ownership: Assessing Corporate Control Mechanisms in the Netherlands, February 2003

865 Bernard M.S. van Praag and Pedro Cardoso, The Mix Between Pay-as-you-go and Funded Pensions and what Demography has to do with it, February 2003

866 Ernst Fehr, Urs Fischbacher, Bernhard von Rosenbladt, Jürgen Schupp, and Gert G. Wagner, A Nation-Wide Laboratory. Examining Trust and Trustworthiness by Integrating Behavioral Experiments into Representative Survey, February 2003

867 Frank Heinemann, The Inflationary Impact of Wage Indexation, February 2003

868 Eytan Sheshinski, Bounded Rationality and Socially Optimal Limits on Choice in a Self-Selection Model, February 2003

869 M. Hashem Pesaran, Estimation and Inference in Large Heterogenous Panels with Cross Section Dependence, February 2003

870 Luis H. R. Alvarez and Erkki Koskela, On the Tree-Cutting Problem under Interest Rate and Forest Value Uncertainty, February 2003

871 Norbert Berthold and Rainer Fehn, Unemployment in Germany: Reasons and Remedies, February 2003

872 Clemens Fuest, Bernd Huber, and Philipp Tilleßen, Tax Policy and Entrepreneurship in the Presence of Asymmetric Information in Capital Markets, February 2003 